\title{
The Construction of Yakshas in Chinese Religious Paintings, Statues and Classics
}

\author{
Xiaodong Li \\ School of History and Culture, Sichuan University, Chengdu, Sichuan, China
}

Keywords: Buddhism, Yaksha, Paintings, Statues, Construction.

\begin{abstract}
The investigation of the semantic evolution of Yakshas and the reasons why the word "Yaksha" occupies the monopoly status of the discourse; the narrative tendency of Yakshas in mystery texts of Tang Dynasty; Chinese native Buddhist paintings, statues focused on shaping the positive and negative image of the Yaksha while the narration in classics reflected the status symbol and self-identity of ancients, the explanation of life and the universe, the ethic and values, the cognition of Yakshas and the conflict between farming and nomadic civilization, etc. The construction of the two aspects formed the native Yaksha culture; The native Yaksha discourse is a part of metaphysical cognition and imagination. It is the reflection of people's spirit and mentality. To some degree, it is also an expression of "evil human nature-power".
\end{abstract}

\section{Introduction}

In real life, the memory of Yakshas is blurred. The word "female yaksha" is seldom used to describe a shrew. It has become a word only existing in the text of Yakshas or dictionaries. Yaksha, in the context of history, like its secret behavior style, is extremely unobtrusive.

Although Yaksha is an edge historical discourse, the memories and images of Yaksha are still occasionally or intermittently reproduced in different contexts. For example, Traditional martial arts Shaolin Cudgel techniques has some routines known as "great Yaksha" and "little Yaksha"; the writer Rugai Mu has a novel called Yaksha ,the beauty and there is a novel called Golden Yaksha written by Japanese writer Ozaki Koyo in Meiji period; The dried rattan stems of Chinese medicine Polygonum multiflorum are called "Yaksha vines"; A kind of succulent plants is called "Yaksha lady " in Japan; there is also a rock band set up in 1995 called "Yaksha" in Sichuan of China, etc.

On the basis of the study of Yaksha made by many scholars, this paper focuses on the literature of Chinese Buddhism, the narrative reform and evolution of Yaksha in Chinese native literature, the status and influence of Yaksha in the history of mystery narration, and the characteristics of Yaksha narration. It also tires to reveal the cultural meaning of Yaksha by combining paintings and statues of Yaksha in native religious culture.

\section{The Evolution of the Concept of "Yaksha"}

Yakshas, written in Sanskrit, transliterates as Yue Cha, Yao Cha, Ye Cha, Yao Qisa, Ye Qicha and so on. Ying Xuan(Yuan)(Tang Dynasty) thought "Yao Cha" was the correct transliteration and others were wrong in his book The Sound and Meaning of the Tripitaka. However, the name was unified as "Ye Cha" eventually. There are two reasons roughly. Firstly, the word "Ye Cha" has been spreaded]] in folk during Tang Dynasty. "Yeksha" was mentioned 20 times in New Book of Dunhuang Narrative Literature, 19 times are used as "Ye Cha". "Yao Cha" is only used once. Secondly, it is most likely due to the definition of "Ye Cha" in the book Taiping Hiroki of Northern Song Dynasty. The Chinese version of Yakshas is an example of making the transliteration meaningful.

Yaksha is strong and powerful with rapid speed. It is often translated as "a ghost of rapidness" or "a ghost of power". Yaksha is used to suck human's vital essence and eat their flesh and blood. Thus, it is also translated as "a feeding ghost", "a ghost of ancestor worshipping" or "a harmful ghost". Besides, 
there are some other translations, such as "secret", "man of rank"(because it is one of the eight kinds of dragon beings ). The Chinese version of Yaksha was given the image of holding the trident(the symbol of lightening), the fishgig or the halberd, which added its sense of violence. In the battle of names of Yakshas, "Ye Cha" finally won and took the place of discourse monopoly. Other transliterations have been forgotten gradually. In general, Yaksha is transformed through Sanskrit to Chinese, and gets into the traditional Chinese ghost world through language, and then enlarges its boundaries of religious classics to the social secular cultural life by combining with Chinese people's world of death. In the soil of Chinese culture, Yaksha shows another vitality.

\section{The Narrative Diversion of Yakshas in Mystery Culture}

The mystery texts before Tang Dynasty continued the concept of "animism" and "polytheism" and emphasized the narration of gremlins like animal gremlins, plant gremlins, implement gremlins and landscape gremlins, and the narration of gods and human beings like witches, ghosts, gods and celestial beings. From Tang Dynasty, the tendency of narration changed into Yakshas and once became the main topic. Tang Dynasty's intellectual class led the trend of narrative diversion by the orthodox classical narration. Taiping Hiroki of Northern Song Dynasty collected various mystery texts and set two chapters for Yakshas, which intensively reflected this kind of diversion.

There are two typical characteristics of Yaksha narration in Tang Dynasty: Firstly, Yakshas were inseparable from the night, and the invisible and mysterious Yakshas were lurking or appearing at night or in darkness. Secondly, the narration focused on the experiences between Yakshas and humans and expressed the interaction of each other and the elimination of their intense condition. Surrounded by these two aspects, the authors in Tang Dynasty unfolded various and colorful narration of Yakshas. The influence extended to Qing Dynasty, especially showed in Songling Pu's works of mystery texts.

\section{The Construction of Native Yaksha Culture}

The Yakshas in Indian culture once melt into Chinese world where has its tradition of mystery culture, recreates by native authors, combines the religious paintings and statues (Buddhism mainly) and eventually forms native Yaksha culture.

The Culture of Yakshas in Religious Paintings and Statues. The image of Yakshas in paintings and statues is described according to Buddhism classics. The main purpose is to demonstrate the Mahayana doctrine of obedience, faith, worship and protection. Most of these Yakshas act as the supporting roles of Buddha and bodhisattva. They are usually males and show in front of believers and the public in three ways:

First, the positive and kind image of Yakshas is constructed as the patron saints such as deva-kings, dorjes, mallas. They are also classified as Yakshas in heaven and Yakshas in hell. The style evolved into a western, Han or Tibetan style, but the facial expression is the same as that of India, which is a style of angry and prestigious.

Second, the negative image of Yakshas is constructed as the demons surrendered by deva-kings or dorjes. Most of them are Yakshas in hell who are constructed as ugly and wretched.

Third, there is still another type of Yakshas which hold the image of expressing happiness and respect. Such as gigaku Yakshas who are good at dancing and music.

According to the scholar's study, native Yakshas' religious paintings and statues are widely distributed in Kizil grottoes, Anxi grottoes, Maijishan grottoes, Dunhuang grottoes, Yungang grottoes and Longmen grottoes. They also exist in some individual tombs, potteries and folk woodcuts. The Yakshas showed in paintings and statues are mainly the flying ones, dorjes, mallas or vaisravana. These Yakshas are also becoming more localized. In the aspect of male Yakshas, combining with famous military generals, deva-kings, dorjes, mallas has evolved into statues that the public believed in, such as Heng Ha deva-kings, four devarajas or four deva-kings, door-gods. The identity of the Yakshas was blurred. In the aspect of female Yakshas, the female image(Hariti, the god of good-harvest, plague, protecting babies) which is popular in India gradually disappeared in 
China. Moreover, the image turned into viragos. This is a feature of the local acceptance of the Yaksha culture.

The Narration of Yakshas in the Texts. Except the Buddhist texts in Chinese version, the related literature appeared during Jin Dynasties. For example, In the book History of Wei Dynasty, there are records of "Yaksha" used by elites in the Northern Dynasties. This is a typical example that Yakshas go into people's daily life with the prevalence of Buddhism in China.

During Tang Dynasty and Song Dynasty, the culture of Yakshas in China was popular. Combined with local mystery, the ghost image of Yakshas was strengthened mainly through the narration diversion during Tang Dynasty and the Five Dynasties, and the Yakshas' stories collected in Taiping Hiroki of Song Dynasty. The mystery stories before Tang Dynasty regained vitality by combaining the culture of Yakshas.

After Tang Dynasty, in addition to the mystery literature, there were also records of Yakshas dancing in palaces in the history books. In the context of "the unity of the three religions" and the folk religion, some certain Yakshas have been sinicized. For example, vaisravana and his son, Hariti and so on. In Yuan, Ming and Qing Dynasty, sometimes there were also the narration of Yakshas in dramas and novels, and unexpectedly there were actors with the figure of Yakshas in the legitimate dramas during Ming and Qing Dynasty.

Yaksha has become a main character in mystery books since it was introduced into China even though he was always marginalized, vulnerable, unloved and unvalued. At least nine levels of cultural meanings can be found in the narration of Yakshas and historical materials accumulated in the past dynasties.

As a status symbol. Mystery stories and novels constructed "female Yakshas"(fierce wives), "sexy Yakshas"(seduce males)and "kind Yakshas"(mighty wives); Few people paid attention to the "parading Yakshas" who were in a lower status of "power-society" written in full-length novels during Ming and Qing Dynasty. In Twenty-Four Histories (dynastic histories from remote antiquity till the Ming Dynasty) and other literatures, there was no shortage of real historical figures with the name or nickname of "Yaksha", which was generally associated with the power elites, namely, with civil officers and the military officers.

Yakshas in dance and drama art. In court rites and music of Mongolia, Tibet and Han nationality in Yuan dynasty, there were male dancers dressing as "Vaishravana" and "flying Yakshas"; In Qing Dynasty, there were mountain gods and Yakshas in the drama The Peach Blossom Fan, as a symbol of retribution of powerful ministers Shiying Ma and Dacheng Ruan in Nan Ming Dynasty.

Yakshas and metaphysical explanations. The Tang Dynasty put forward an explanation for life, society and the universe with Yakshas. For example, the encounter with Yakshas resulted in bad luck or good luck for a part of elites; The assassins' skills were taught by flying Yakshas; The mixing of Yakshas into human society was one of the causes of the plague; The comet was formed by the smoke coming from Yaksha's mouse. People in Qing Dynasty believed that zombies would change into flying Yakshas. Only lightning or fowling pieces could kill zombie Yakshas.

Yakshas and heroism. In mystery books of Tang Dynasty, the confrontation between the minority and Yakshas were often used to show individualistic heroism or masculinity. For example, Zidong Wei in Zhenyuan period and Yueshi Chen of Yuanhe period of Tang Dynasty who beat Yakshas.

Wine and Yaksha cognition. The mystery books of Qing Dynasty linked Yakshas with wine culture. Yakshas were described as alcoholics and often snuck into human's world to drink. It made the Yaksha stories more interesting. The intellectuals of Qing Dynasty began to doubt the spectre of Yakshas because of the drinking problem. The focus moved from the stories to Yaksha itself.

Flying Yakshas and sexual instinct. The flying Yakshas are usually male. In mystery texts of Tang, Ming and Qing Dynasty, people sometimes described flying Yakshas as dangerous and alluring women, which became the target of male unconscious fantasies.

Yakshas and ethics. In the texts of Yakshas, the complicated side of ethics and morality is expressed by the conversion of humans and Yakshas . People in Tang Dynasty thought that women may transformed into Yakshas; Yasha wouldn't subject to Confucian ethics when they married their wives; When they got married, they need the help of paulownia wood figurines made by humans; The 
babies they had would be Yakshas or Rakshasas; Human beings would give birth to Yakshas for no reason.

Yakshas and Values of Confucianism and Buddhism. Yakshas are sometimes described as protectors of agriculture and animals. The reason why people are told not to kill cows and eat beef by Yakshas is that cows are the driving force of agricultural civilization. Yakshas are also the firm guardians of the values of Confucianism and Buddhism. They will punish monks who violate the discipline of sex and bring good luck to those who are loyal to the Confucianism.

Yakshas and civilization conflicts. Classics and mystery texts shows that some people from Han nationality in Tang, Ming and Qing Dynasty discriminated against ethnic minorities or foreign ethnic groups around them by comparing these people with Yakshas. Their residence was known as "Yaksha's city" or "Yaksha's country". This represents a sense of superiority to ethnic and foreign minorities, as well as the superiority of the agricultural civilization to the fishing and hunting civilization or the nomadic civilization.

\section{Conclusion}

After researching on the construction of native religious paintings, statues and texts, how do we view the cultural phenomenon of Yakshas? The author believes that at least three aspects can be considered:

Yakshas are a part of the metaphysical cognition and imagination in Chinese culture. Yakshas in the texts are rooted in the context of nature and the universe with animalism, human nature and divinity(spectre). They are partly hidden and partly visible in the sky, water and land. They sometimes appear in hell and sometimes not. They keep the human's world at an arm's length. The texts carry the author's discovery and curiousness toward the mysterious world and give an explanation to Yakshas.

Yakshas is the reflection of people's spirit and mentality. Yakshas are included in the secular context of Chinese culture "wine, sex, wealth and pride". They are the negative symbol of every evil feature such as ugly, bad, strange, fierce and inferior. They become a tool which arouses people's bad experience such as astonishment, fear and hatred.

Behind all sorts of weird, regardless of Chinese and Indian culture, the "nonhuman" Yakshas, to some extent, are the expression, symbol or metaphor of the instinct of "evil human nature-power " . It is a kind of representation of mind. This is the most common discourse meaning. It is not Yakshas that seek out human beings, but human nature that must be expressed through Yakshas. The assumption of confrontation with diabolism and Yakshas, or making depraved Yakshas be good, makes the ancient Buddhism express the legitimacy of the existence of itself in the living beings, and promotes the "goodness" word of Buddhism. People surrender to you not because of gratitude, but a sense of afraid. It is a kind of human nature. Yakshas can bring people a sense of security which meets this aspect of human nature. It is like the nature of power. Whether the destruction of natural forces or the mutilation of evil human nature and authority, the people themselves are anxious or worried, and that makes Yakshas become a barrier of psychological defense. It is dreadful to see Yakshas have the flesh and blood of humans. However, it is more chilling and awe-inspiring for devarajas or deva-kings who are able to conquer Yakshas. Human beings can still escape from the chase of Yakshas. They can fight against Yakshas even when they are in deep hopelessness. However, When facing deva-kings or devarajas, humans have no choice but obedience. It implies power control in the context of supernatural power.

\section{References}

[1]Chongyu Liu: China's Gremlin Culture, Shanghai: Shanghai People's Publishing House, 1997.

[2]Jianguo Li: The Legendary Narration of Tang and the Five Dynasties, Tianjin: Nankai University Press, 1993. 
[3]Yahui Zhang: Abstract of the Study of Yaksha's Image in Chinese Buddhist Classics, Master's thesis, Department of Chinese Literature, Chung Cheng University, Taiwan, 2000, Taiwan's Doctor's and Master' s paper value - added system http://ndltd.ncl.edu.tw/cgi-bin/gs32/gsweb.cgi/ccd= WfxSpM/record?r1=1\&h1=0\#XXX, August 12, 2010

[4]Edited by Fubao Ding : Buddhist Dictionary, Item "Yaksha", Internet version, http://foxue.supfree.net/, June 10, 2010

[5]Chonggui Pan: New Book of Dunhuang Narrative Literature, Taiwan: Central Research Institute, Chinese electronic literature, Modern Chinese Corpus http://hanji.sinica.edu.tw/, October 22, 2014.

[6]Edited by Fang Li and others: Taiping Hiroki, Hainan: Hainan International Press and Publication Center, 1996.

[7][Japan] Nakano Miyoko: Monsters in China, Henan: Henan Yellow River Literature and Art Publishing House, 1989.

[8] [English] Fiona Bowie, Ze Jin, He Qimin translated: Introduction to Religious Anthropology, Beijing: Renmin University of China Press, 2004. 